\title{
Allergic Diseases Caused by Aspergillus Species in Patients with Cystic Fibrosis
}

\author{
Aidan K. Curran ${ }^{1}$ (1) and David L. Hava ${ }^{2, *}$ \\ 1 Pulmatrix Inc., 99 Hayden Avenue, Lexington, MA 02421, USA; acurran@pulmatrix.com \\ 2 Synlogic Inc., 301 Binney Street, Cambridge, MA 02142, USA \\ * Correspondence: dave.hava@synlogictx.com
}

Citation: Curran, A.K.; Hava, D.L. Allergic Diseases Caused by Aspergillus Species in Patients with Cystic Fibrosis. Antibiotics 2021, 10, 357. https://doi.org/10.3390/ antibiotics10040357

Academic Editor: Claudia Cafarchia

Received: 31 January 2021

Accepted: 24 March 2021

Published: 28 March 2021

Publisher's Note: MDPI stays neutral with regard to jurisdictional claims in published maps and institutional affiliations.

Copyright: (c) 2021 by the authors. Licensee MDPI, Basel, Switzerland. This article is an open access article distributed under the terms and conditions of the Creative Commons Attribution (CC BY) license (https:// creativecommons.org/licenses/by/ $4.0 /)$.

\begin{abstract}
Aspergillus spp. are spore forming molds; a subset of which are clinically relevant to humans and can cause significant morbidity and mortality. A. fumigatus causes chronic infection in patients with chronic lung disease such as asthma, chronic obstructive pulmonary disease (COPD) and cystic fibrosis (CF). In patients with CF, A. fumigatus infection can lead to allergic disease, such as allergic bronchopulmonary aspergillosis (ABPA) which is associated with high rates of hospitalizations for acute exacerbations and lower lung function. ABPA results from $\mathrm{T}_{\mathrm{H}} 2$ immune response to Aspergillus antigens produced during hyphal growth, marked by high levels of $\operatorname{IgE}$ and eosinophil activation. Clinically, patients with ABPA experience difficulty breathing; exacerbations of disease and are at high risk for bronchiectasis and lung fibrosis. Oral corticosteroids are used to manage aspects of the inflammatory response and antifungal agents are used to reduce fungal burden and lower the exposure to fungal antigens. As the appreciation for the severity of fungal infections has grown, new therapies have emerged that aim to improve treatment and outcomes for patients with CF.
\end{abstract}

Keywords: allergic bronchopulmonary aspergillosis; cystic fibrosis; anti-fungal; itraconazole

\section{Pulmonary Aspergillus Infections}

Aspergillus spp. are ubiquitous spore forming molds, a subset of which are clinically relevant to humans and can cause significant morbidity and mortality. Pulmonary infection from A. fumigatus, the most common Aspergillus pathogen, causes a diverse set of diseases, ranging from acute invasive disease to long-term, chronic infections [1]. The type of disease and disease severity are largely dictated by the immune system of the host. Immunosuppressed patients, such as those undergoing organ transplantation or cancer treatment, are at high risk for invasive aspergillosis (IPA). IPA is a life-threatening disease that occurs following the inhalation of fungal conidia and the evasion of host defense that allows the fungus to invade host tissues and grow unchecked in the lung [2]. The mortality rate of IPA can be as high as $90 \%$ in some patient populations [3,4] and prophylaxis using oral antifungal drugs is commonly used to prevent infections. Chronic pulmonary aspergillosis is distinct from IPA and manifests in a variety of different diseases including aspergilloma, cavitary disease and fibrosing disease [5]. Patients with chronic lung disease such as asthma, chronic obstructive pulmonary disease (COPD) and cystic fibrosis $(\mathrm{CF})$ are susceptible to chronic aspergillosis.

Chronic diseases caused by Aspergillus can result from stable active infection of the lung or from allergic sensitization resulting from the exposure to Aspergillus antigens. In the first case, disease results from stable and persistent infection of the airways with Aspergillus resulting in fungal growth and an inflammatory response that aims to clear the infection from the lung. In some instances, this has been referred to aspergillus bronchitis [6], which may have a varying impact on lung function and clinical disease. In contrast, allergic diseases, characterized by a $\mathrm{T}_{\mathrm{H}}$ 2-driven immune response to Aspergillus antigens, include both severe asthma with fungal sensitization (SAFS) and allergic bronchopulmonary aspergillosis (ABPA). Both SAFS and ABPA are significant clinical issues in patients with 
asthma, with the latter being a significant clinical problem in patients with $\mathrm{CF}[7,8]$. $A$. fumigatus is the common cause of ABPA, however sensitization to other Aspergillus species has been noted [9]. In the case of allergic disease, the resulting allergic response to antigen is likely independent of the specific Aspergillus species. It has been suggested that there may be a continuum of disease that starts with aspergillus bronchitis and progresses to sensitization and ultimately ABPA [6], for the purposes of this review, we primarily focus on aspergillus bronchitis and APBA in patients with CF.

While the clinical impact of Aspergillus colonization and persistence may vary among patients and require continued characterization, allergic fungal infections have a clear deleterious clinical impact. CF patients with sensitization to A. fumigatus antigens have a distinct and robust $\mathrm{T}_{\mathrm{H}} 2$ inflammatory response in sputum samples after allergen challenge. This inflammation is marked by increases in sputum eosinophils and increased expression of IL-5 and IL-13 [10]. ABPA is characterized by a complex $\mathrm{T}_{\mathrm{H}} 2$ hypersensitivity reaction in response to fungal antigens that drives immune cell activation and eosinophil recruitment (Figure 1) [11,12]. Expression of IL-4 and IL-5 are central to these processes. IL-4 stimulates the upregulation of adhesion molecules involved in eosinophil recruitment and the production of IgE by B cells, which in turn leads to mast cell activation. IL-5 produced by both $\mathrm{T}_{\mathrm{H}} 2$ cells and mast cells is a key mediator of eosinophil activation. Activation of both mast cells and eosinophils results in the release of mediators that induce bronchoconstriction (Figure 1) [12]. Through repeated cycles of inflammation, patients with ABPA are at high risk for frequent exacerbations and the development of bronchiectasis [1].

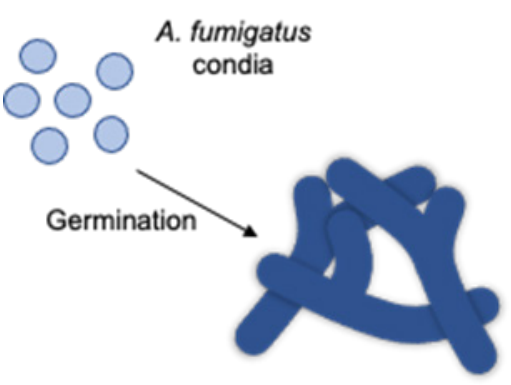

A. fumigatus hyphae

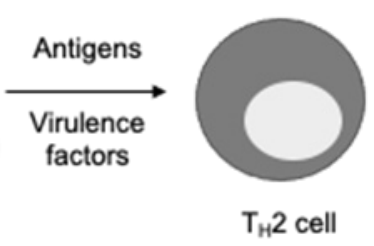

$\mathrm{T}_{\mathrm{H}} 2$ cell

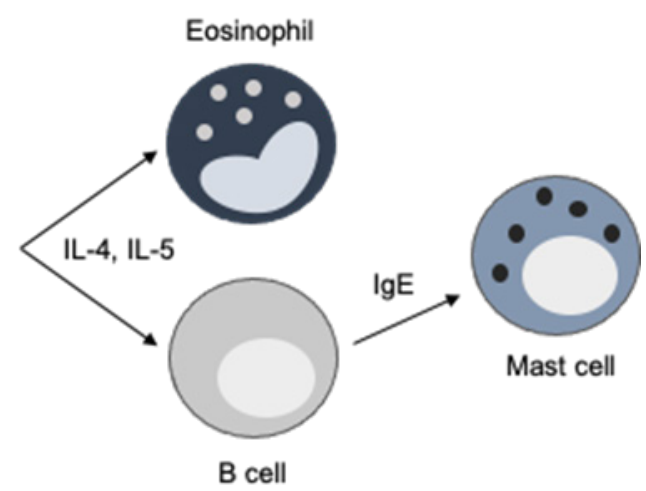

Figure 1. Pathophysiology of ABPA. Inhalation of fungal conidia and subsequent germination of fungal hyphae results in the expression of antigens specific to hyphal growth. These antigens are recognized by the immune system and cause a $\mathrm{T}_{\mathrm{H}} 2$ driven immune response marked by increased levels of $\mathrm{T}_{\mathrm{H}} 2$ cytokines, recruitment of eosinophils to the lung and increased production of IgE. The activation of eosinophils and mast cells drive the pathophysiology of ABPA and the resulting clinical symptoms.

\section{Prevalence and Diagnosis of Aspergillus Infections in Patients with CF}

Chronic aspergillosis and ABPA affect a large number of patients each year, with more than 3 million cases of chronic disease and nearly 5 million cases of ABPA reported on an annual basis $[7,13]$. The majority of ABPA represents disease in asthmatics, with an estimated 1 to $2.5 \%$ of all asthmatics worldwide having ABPA [14]. Reports of ABPA prevalence in patients with CF vary from 1 to $15 \%[15,16]$, with reports of colonization rates in respiratory samples ranging from 6 to $58 \%[13,17,18]$. The variability in these reports is likely at least partially due to differences in sample collection, processing and diagnostic approaches between laboratories.

A. fumigatus is the most common species present in the lungs of patients with $\mathrm{CF}$, however, other Aspergillus species are clinically relevant, including $A$. niger, A. terrus and $A$. flavus $[15,19,20]$. The prevalence of Aspergillus in adult CF patients has been appreciated for a number of years, with increased prevalence associated with prophylactic antibiotic use [21,22]. More recently, an increase in prevalence has been observed in young children 
with CF [23-25]. In infants with CF, Aspergillus spp. were detected in bronchoalveolar lavage (BAL) samples with similar prevalence and at similar ages as the common the bacterial colonizers Staphylococcus aureus, Pseudomonas aeruginosa, and Haemophilus influen$z a e$. However, whereas S. aureus and P. aeruginosa prevalence decreased over time due to antibiotic therapy, Aspergillus prevalence remained unchanged [23].

An appreciation for the clinical significance of Aspergillus colonization and persistence has increased in recent years. Several studies have suggested an association between $A$. fumigatus infection, respiratory function and severe pulmonary exacerbations. In several studies, CF patients with chronic $A$. fumigatus infection have lower percent predicted forced expiratory volume $\left(\mathrm{FEV}_{1}\right)$ than uninfected controls [17], higher rates of hospitalization resulting from pulmonary exacerbations [17], show more rapid loss of lung function [24,26,27] and have worse respiratory quality of life [28]. Declines in clinical disease are a result of increased pulmonary inflammation $[29,30]$, which can also result in structural lung changes by high-resolution CT (HRCT) scan. In a cross-sectional study of children, BAL samples positive for Aspergillus were associated with air-trapping on HRCT, although the same study failed to show an association with lung function decline between the ages of 5 and 14 [31]. A recent longitudinal study of 330 children found similar findings linking Aspergillus culture positivity to changes in structural lung disease [30]. Aspergillus infection was associated with worse initial CT scores that declined further in the subsequent year, with the most significant impact on air-trapping and mucus plugging [30]. Interestingly, the magnitude of disease progression was associated with the number of Aspergillus infections over the course of the study, suggesting a dose-responsive relationship between infection and disease. A similar association with progression of lung diseases was observed for $P$. aeruginosa infection, but not for $S$. aureus and $H$. influenzae infections.

An understanding of incidence and prevalence is further hampered by the difficulty of diagnosing disease. Diagnostic criteria for ABPA include both obligatory and supportive criteria in addition to having either asthma or CF. High levels of serum IgE $(>1000 \mathrm{U} / \mathrm{mL})$ and a positive hypersensitivity skin test or increased IgE antibody to Aspergillus are required criteria together with at least two additional supportive features: eosinophilia $(>500$ cells $/ \mu \mathrm{L})$, Aspergillus-specific IgG, and/or radiographic findings [32]. ABPA is characterized clinically by wheezing, dyspnea, mucus production and productive cough and bronchoconstriction. Repeated episodes of mucus production, bronchial obstruction and inflammation may lead to bronchiectasis and, in severe cases, pulmonary fibrosis, which collectively result in a progressive loss of lung function. A combination of clinical symptoms and biomarkers have been used to develop a staging system to help in disease management [32].

The range of reported disease prevalence and variations in diagnostic approaches suggests that pulmonary fungal infections in CF may be under diagnosed. This is further complicated by the use of culture-based diagnostic methods, which underestimate Aspergillus detection compared to molecular methods, such as quantitative PCR [6,33]. New methods to detect Aspergillus in sputum using RT-PCR and high-volume culture techniques have the potential to significantly increase the sensitivity of detection and ultimately, diagnosis $[13,34]$. Using these new culture techniques, CF patients can be put into four subgroups; those without aspergillosis, those sensitized to Aspergillus, those with ABPA and those with aspergillus bronchitis [13]. Using this methodology, Baxter et al. classified $130 \mathrm{CF}$ patients and found that $30 \%$ had aspergillus bronchitis and $17.7 \%$ had ABPA. Armstead et al. compared these rates to the reported rates of ABPA in CF registries and literature reports for adult $\mathrm{CF}$ patients from 30 different countries [35]. They found that the number of ABPA cases diagnosed and reported is likely a significant underrepresentation of the estimated cases when more sensitive diagnostic assays are utilized. In the United States the number of documented adult CF cases of ABPA (869 cases) was $34.6 \%$ of the estimated cases ( 2510 cases) as defined by Armstead et al. Using the more recent data, almost $50 \%$ of US adult CF patients may have either ABPA or aspergillus bronchitis [35]. 


\section{Aspergillus ssp. and Bacterial Interactions in the Pathogenesis of Disease}

CF patients have a complex lung microbiota, where there is likely significant interplay between colonizing bacteria and fungi [36]. Longitudinal assessment of data from the Cystic Fibrosis Foundation Patient Registry suggests that P. aeruginosa and Stenotrophomonas maltophilia infections are positively correlated with Aspergillus infections [37]. In contrast, infection with Burkholderia cepacia complex was negatively associated with both current and future Aspergillus infection [37], indicating that there are specific mechanisms in different bacteria that influence the susceptibility of patients to Aspergillus infections. Potential interactions between Aspergillus species and non-tuberculous mycobacterial (NTM) infections have not been well characterized. Given the importance of NTM infections in CF [38] and the suggestion that $A$. fumigatus can negatively impact NTM infection in mice [39], a more detailed assessment of the impact of co-infection with these pathogens is needed.

In CF patients, the most common bacterial and fungal isolates are P. aeruginosa and A. fumigatus, respectively [40] and colonization with both species results in greater lung function decline relative to individuals with either infection alone [17,41]. Given the relationship between bacteria and fungi, there is growing interest in understanding how these infections interact, influence each other and affect the progression of CF-related disease. In particular, it is important to understand how the treatment of one infection may increase or decrease susceptibility to another infection. Indeed, in clinical practice, antibiotic treatment has been shown to predispose CF patients to Aspergillus colonization [22].

Both $P$. aeruginosa and $A$. fumigatus form biofilms in vivo and in vitro [42,43]. Several reports suggest that $P$. aeruginosa inhibits $A$. fumigatus planktonic growth and biofilm formation by secreted factors and different isolates of $P$. aeruginosa exhibit different degrees of toxicity $[41,44]$. P. aeruginosa inhibits $A$. fumigatus growth by the production of pyoverdine, a siderophore that sequesters iron. P. aeruginosa mutants defective in pyoverdine production are not toxic to A. fumigatus, and the addition of pyoverdine to mutant cultures restores A. fumigatus toxicity [45]. More research will be required to understand not only the in vivo balance between these pathogens, but also the effect of these interactions and individual eradication treatments on patient outcomes.

S. maltophilia is a Gram-negative pathogen of increasing significance in CF. Data from an in vitro mixed-culture biofilm model of A. fumigatus and S. maltophilia suggest an inhibitory effect of $S$. maltophilia on A. fumigatus growth and production of extracellular matrix [46]. Co-culture of these organisms also impacts their susceptibility to antibiotics. Susceptibility of A. fumigatus to amphotericin B was increased in mixed-culture biofilms, whereas S. maltophilia susceptibility to levofloxacin decreased [47]. These data highlight potentially clinically relevant, complex interactions between $A$. fumigatus and bacteria other than P. aeruginosa. Further study of interactions between A. fumigatus and bacteria commonly found in the CF patients is warranted.

\section{Treatment of ABPA with Approved Therapies}

In addition to managing the symptoms of asthma or $\mathrm{CF}$, treatments targeted at treating ABPA aim to prevent acute exacerbations, reduce pulmonary inflammation and to prevent progression toward end-stage fibrotic disease [48]. While there are no approved therapies for ABPA, much of our understanding of how to treat ABPA in CF patients comes from clinical trials conducted in asthmatics with ABPA. Oral corticosteroids are used in an effort to suppress inflammation and oral antifungals are used in an attempt to eradicate Aspergillus from the airways to reduce antigen stimulation of the allergic response [49]. Therapeutic effects are typically monitored through changes in serum IgE levels while tapering steroids until remission is observed [11,49]. Improvements in pulmonary function are a desired impact of therapy, however, deterioration of lung function in patients with APBA is variable, with some patients maintaining stable lung function and others presenting with progressive deterioration [50,51]. Current ABPA treatment paradigms have been informed by a number of clinical trials that have evaluated the effects of approved anti-inflammatory and anti-infective therapies on ABPA clinical disease (Table 1). 
Table 1. Randomized, controlled clinical trials conducted in ABPA.

\begin{tabular}{|c|c|c|c|c|c|c|}
\hline Drug & Dose & Design & $\mathbf{N}$ & Duration & Primary Outcome & Reference \\
\hline Prednisolone & $\begin{array}{l}0.5 \mathrm{mg} / \mathrm{kg} \text { * } \\
0.75 \mathrm{mg} / \mathrm{kg} \text { * }\end{array}$ & $\begin{array}{l}\text { Randomized, } \\
\text { controlled }\end{array}$ & 92 & $\begin{array}{c}6 \text { to } 8 \text { weeks } \\
\text { followed by taper } \\
\text { for up to } 10 \text { months }\end{array}$ & $\begin{array}{c}\text { Exacerbation rate } \\
\text { Steroid-dependent } \\
\text { ABPA }\end{array}$ & [49] \\
\hline $\begin{array}{l}\text { Itraconazole } \\
\text { Prednisolone }\end{array}$ & $\begin{array}{l}200 \mathrm{mg} \text { BID } \\
0.5 \mathrm{mg} / \mathrm{kg} \text { * }\end{array}$ & $\begin{array}{l}\text { Randomized, } \\
\text { controlled }\end{array}$ & 131 & 16 weeks & $\begin{array}{c}\text { Composite clinical } \\
\text { response } \\
\text { Decline in IgE } \\
\text { Exacerbation rate }\end{array}$ & [52] \\
\hline Itraconazole & 400mg QD & $\begin{array}{l}\text { Randomized, } \\
\text { double blind, } \\
\text { placebo } \\
\text { controlled }\end{array}$ & 29 & 16 weeks & $\begin{array}{l}\text { Sputum eosinophil } \\
\text { count }\end{array}$ & [53] \\
\hline Itraconazole & 200mg BID & $\begin{array}{l}\text { Randomized, } \\
\text { double blind, } \\
\text { placebo } \\
\text { controlled }\end{array}$ & 55 & 16 weeks & $\begin{array}{l}\text { Composite clinical } \\
\text { response }\end{array}$ & [54] \\
\hline $\begin{array}{l}\text { Voriconazole } \\
\text { Prednisolone }\end{array}$ & $\begin{array}{l}200 \mathrm{mg} \text { BID } \\
0.5 \mathrm{mg} / \mathrm{kg} \text { * }\end{array}$ & $\begin{array}{l}\text { Randomized, } \\
\text { controlled, } \\
\text { unblinded }\end{array}$ & 50 & 16 weeks & $\begin{array}{l}\text { Composite clinical } \\
\text { response } \\
\text { Exacerbation rate }\end{array}$ & [55] \\
\hline $\begin{array}{c}\text { Inhaled } \\
\text { amphotericin B }\end{array}$ & 10mg BID & $\begin{array}{l}\text { Randomized, } \\
\text { controlled }\end{array}$ & 21 & 16 weeks & $\begin{array}{l}\text { Time to first } \\
\text { exacerbation }\end{array}$ & [56] \\
\hline Omalizumab & $600 \mathrm{mg}$ & $\begin{array}{l}\text { Randomized, } \\
\text { double blind, } \\
\text { placebo } \\
\text { controlled }\end{array}$ & $14^{* *}$ & 24 weeks & $\begin{array}{l}\text { Requirement for } \\
\text { rescue } \\
\text { corticosteroids }\end{array}$ & NCT00787917 \\
\hline
\end{tabular}

* Starting doses, regimens involved a pre-specified reduction in dose and tapering regimen; ${ }^{* *}$ Discontinued due to poor enrollment.

\subsection{Oral Corticosteroids}

The use of corticosteroids in treating ABPA in asthma has largely been based on experience in clinical practice with few randomized, controlled clinical trials studying steroid use as chronic therapy. Long-term steroid use is associated with adverse sideeffects, which must be managed in parallel with the management of ABPA $[12,57,58]$ and long-term steroid increases the risk of developing corticosteroid-dependent disease. Although studies on steroid use in patients with relapsing and chronic disease are lacking, two recent clinical studies have evaluated corticosteroid use in acute treatment naïve ABPA patients, with positive results. A comparison of high-dose and medium-dose steroid regimens in treatment-naïve ABPA patients found that both treatment protocols resulted in a similar number of acute exacerbations after 1 year and a similar number of patients with glucocorticoid-dependent ABPA after 2 years. However, the medium-dose group resulted in fewer glucocorticoid side-effects [49]. In a similar clinical study comparing prednisolone treatment to itraconazole treatment, a similar medium steroid dose resulted in high rate of clinical response and reduced IgE levels [52]. The lower steroid doses used by Agarwal et al. are similar to common treatment regimens world-wide [59].

\subsection{Anti-Fungal Therapy}

Use of antifungals in management of ABPA is supported by a strong biological link between Aspergillus infection in the airway and the resulting allergic inflammatory response that is the hallmark of ABPA inflammation. A high percentage of asthmatics sensitized to $A$. fumigatus are sputum culture-positive for A. fumigatus growing in their airways [6], which correlates with reduced lung function [60]. Fungal spores are largely non-inflammatory and allergic disease is primarily driven by antigens produced in the hyphal growth state [61-63], highlighting the fact that the germination of spores into growing hyphae is necessary for 
eliciting the immune response and the resulting pathophysiology of the disease (Figure 1). That these antigens are expressed in vivo and that they can be reduced by therapies that limit fungal growth is supported by several studies showing that antifungal therapy reduces Aspergillus-specific IgG and IgE [64]. Likewise, in a small study that examined Aspergillus infection in patients with ABPA and SAFS, 9 patients that were positive for Aspergillus infection by PCR became negative for Aspergillus infection following treatment with itraconazole. This conversion was associated with a reduction in total serum IgE [65].

The most common antifungal therapy used in the management of ABPA is itraconazole, a triazole that inhibits fungal cytochrome P450 synthesis of ergosterol, a critical component of the fungal cell wall [66]. Clinically, itraconazole is used to reduce fungal burden and inflammation, and also as a steroid-sparing agent to reduce the long-term usage of corticosteroids. A number of clinical studies and case series have shown the benefit of itraconazole in treating Aspergillus bronchitis [67] and ABPA [53-55,68], including ABPA patients with CF [64]. As with any anti-infective therapy, long term therapy with triazoles can lead to the emergence of resistance [69]. Of particular concern, since the predominant mechanism that azole resistance develops is through mutation of the cyp51A gene, the molecular target of azole activity, the development of resistance to one azole can result in broad cross-resistance to multiple azoles [70]. This concern is further underscored by the recent description of a second mechanism of multiple-azole resistance resulting from mutations in cyp51B, a second 14- $\alpha$ sterol demethylase, which may be further exacerbated by a second mutation in $h m g 1$ [71].

Oral itraconazole efficacy in asthmatics with ABPA has been studied in two randomized, placebo-controlled studies to study the clinical response and anti-inflammatory effect of treatment $[53,54]$. In a study of 55 asthmatics with ABPA, patients were randomized to receive oral itraconazole or placebo for 16-weeks, after which all patients received itraconazole for an additional 16 weeks in an open label extension period [54]. Itraconazole efficacy was assessed using a composite clinical response score that included reduction in corticosteroid use, reduction in IgE and either improved lung function or exercise tolerance. Compared to placebo, oral itraconazole significantly improved clinical responses and more than $70 \%$ of patients on itraconazole lowered their oral corticosteroid dose by more than $50 \%$. In the open-label extension portion of the study 12 of the 33 patients who did not respond in the double-blind portion or were on placebo had a clinical response [54], further underscoring the efficacy of itraconazole in this patient population.

Inflammation resulting from A. fumigatus antigen exposure is the main driver of clinical disease. In a second randomized, double-blind placebo-controlled study the effect of itraconazole on pulmonary inflammation was assessed in 29 subjects with stable ABPA [53]. Over 16 weeks, treatment with oral itraconazole significantly reduced the number of sputum eosinophils and eosinophil cation protein, with a significant reduction observed after only one month of therapy. Serum markers of inflammation, IgE and IgG specific to Aspergillus antigens, were also reduced [53]. More recently, a comparison of steroid therapy to itraconazole therapy in acute, treatment naïve patients found that while there was moderate benefit for steroid therapy over itraconazole ( $100 \%$ vs. $88 \%$ composite response; $p=0.007$ ), itraconazole had a significant benefit to the majority of patients, with fewer side effects than steroid treatment [52].

Although anti-fungal drugs have not been widely studied in CF patients with ABPA, data generated in asthmatics suggests that antifungal therapy may provide benefit to $C F$ ABPA patients. This is further supported by small studies of itraconazole in patients with CF. In a study of itraconazole in six ABPA patients, three of whom had CF, itraconazole treatment reduced steroid use and two of the three CF patients had clinical benefit, including improved lung function [68]. An additional case series of $16 \mathrm{CF}$ patients with ABPA also showed that itraconazole treatment resulted in fewer acute exacerbations and provided a steroid-sparing benefit [72]. In addition to itraconazole, other available azoles such as voriconazole and posaconazole have been used with some benefit in ABPA and $\mathrm{CF}$ [73-76]. In one randomized trial comparing voriconazole and prednisolone, there was 
no difference between the two therapies after 16 weeks of dosing [55]. The opportunity to use anti-fungals in place of high dose, systemic steroids is appealing since long-term steroid use increases the risk of developing diabetes and osteoporosis, and the development of steroid-dependent ABPA is a significant concern [77,78].

Amphotericin B, a polyene anti-fungal that acts by disruption of the fungal cell wall, is commonly used as an intravenous drug to treat severe fungal infections in immunocompromised patients [79]. In an effort to directly target anti-fungal therapy to the lung, inhaled liposomal amphotericin B has been suggested as a treatment option for patients with ABPA and SAFS, however, clinical experience in small studies with inhaled amphotericin has been mixed. In one instance, inhaled amphotericin $B$ reduced exacerbations in patients with ABPA and was reasonably tolerated after the first dose [80]. In other studies, inhaled amphotericin $B$ has been associated with significant tolerability concerns. In a case series study of 177 patients with pulmonary aspergillosis that received inhaled amphotericin B, $66 \%$ of patients were able to tolerate an initial dose, however, $21 \%$ stopped therapy in the following 6 weeks. Only $10 \%$ of patients continued with therapy for more than 3 months, with $28 \%$ of those patients showing improvement in IgE levels [81]. Similarly, in a small clinical study of 21 adult asthmatics with SAFS and ABPA, who had failed previous antifungal therapy, 18 subjects either failed initial dosing or discontinued therapy in the following 12 months [56].

Elevated serum and sputum IgE levels are a hallmark of ABPA. IgE can trigger mast cell degranulation and cause hypersensitivity responses in the lung, which together drive the pathophysiology of the disease [82]. Omalizumab is an anti-IgE monoclonal antibody developed for the treatment of moderate-to-severe uncontrolled allergic asthma. Omalizumab has been used off label in a series of small studies in adults and children with CF and ABPA. In several case reports, omalizumab treatment has shown promise with improved lung function, reduced steroid use and fewer exacerbations in CF patients [83-85]. However, not all studies have shown efficacy with omalizumab [86], and the only well controlled randomized clinical trial was terminated early due to poor enrollment (NCT00787917). Further study is warranted for this approach.

\section{New Therapies to Treat ABPA and Fungal Infections}

Despite the advances in diagnosis and management of ABPA, there remains a significant unmet medical need for the treatment of ABPA. The primary antifungal therapy, oral itraconazole, is generally safe and well tolerated in both CF and non-CF patients, though there is an extensive list of drug-drug interactions (DDI), which requires drug monitoring during therapy. Itraconazole absorption and pharmacokinetics can be highly variable, resulting in inconsistent exposure across patients, which may impact the consistency of clinical responses [68,72]. In healthy volunteers, oral bioavailability of itraconazole is $55 \%$ and is impacted by digestive function [87]. In CF patients, itraconazole exposure is variable and a significant fraction of patients may not achieve therapeutic dose levels. In a study of $11 \mathrm{CF}$ patients, oral itraconazole dosing resulted in sub-therapeutic plasma concentrations in 5 of 11 patients. Low plasma concentrations correlated with variable sputum itraconazole concentrations that were below the reported minimum inhibitor concentrations of itraconazole against $A$. fumigatus [88]. Variable itraconazole pharmacokinetics following oral dosing highlight the challenge of achieving the high, and consistent lung exposure required for efficacy. Consistent with this, a clinical study showing no clinical benefit of itraconazole in CF patients also found that most patients failed to adequate itraconazole exposure [89].

Given the challenges of oral anti-fungal therapy, efforts have aimed to improve the bioavailability of itraconazole to increase exposure in the lungs. One recent approach has been the development of SUBA-itraconazole, an oral formulation with improved pharmacokinetics that rapidly achieves therapeutic levels in the lung [90]. Alternatively, several groups have aimed to use inhalation as an approach to directly deliver anti-fungal agents to the site of disease. Inhalation offers the potential to overcome many of the 
challenges of oral therapies, including achieving high and consistent drug concentrations at the site of infection. Achieving high drug concentrations may limit the emergence of drug-resistant strains or alternatively enable the treatment of drug-resistant infections by achieving concentrations in excess of minimum fungicidal concentrations. Several of these inhalation approaches utilize novel drug delivery technologies to reformulate itraconazole or voriconazole for delivery to the lungs, thereby leveraging the known activity of azoles against $A$. fumigatus. In addition, PC945, a novel azole delivered by liquid nebulization is also in development as a therapy for treating pulmonary fungal infections (Table 2).

Table 2. Novel drugs in development as treatments of ABPA.

\begin{tabular}{cccccccc}
\hline Product & Company & Formulation & Drug & Clinical Trials & $\begin{array}{c}\text { Primary } \\
\text { Indication }\end{array}$ & $\begin{array}{c}\text { Development } \\
\text { Phase }\end{array}$ \\
\hline PUR1900 & Pulmatrix & Dry Powder & Itraconazole & $\begin{array}{c}\text { NCT03479411 } \\
\text { NCT03960606 }\end{array}$ & ABPA & Phase 2 \\
\hline ZP-059 & Zambon & Dry Powder & Voriconazole & NCT04229303 & IPA & Phase 1 \\
\hline TFF-Vori & TFF & Dry Powder & Voriconazole & NCT04576325 & ABPA & Phase 1 \\
\hline PC945 & Pulmocide & Liquid Nebulization & Novel Azole & NCT02715570 & IPA & Phase 1 \\
\hline
\end{tabular}

\section{PUR1900: Inhaled Itraconazole}

PUR1900 (Pulmatrix Inc, Lexington, MA, USA) is a dry powder formulation of itraconazole being developed using a proprietary inhaled delivery technology called iSPERSE [91]. A Phase 1 study in healthy volunteers and adult asthmatic patients (NCT03479411) demonstrated that PUR1900 was safe and well-tolerated. Compared to oral dosing, PUR1900 achieved higher lung and lower plasma itraconazole exposure relative to oral itraconazole treatment [92]. After a single dose of inhaled PUR1900 in asthmatics, therapeutic itraconazole sputum concentrations were observed for over 24 hours in most patients [92].

\subsection{Inhaled Voriconazole}

ZP-059 (Zambon, Milan, Italy) is a dry powder formulation of voriconazole being developed using a novel spray drying technology for the treatment of ABPA in asthma [93]. This formulation was recently evaluated in a Phase 1 study (NCT04229303); however, no results have been reported to date.

TFF-VORI (TFF Pharmaceuticals, Austin, TX, USA) is a dry powder formulation of voriconazole formulated using thin film freezing technology, which produces excipient-free nanoaggregates of drug for inhalation $[94,95]$. A Phase $1 \mathrm{~b}$ clinical safety, tolerability and pharmacokinetic study in adults with asthma (NCT04576325) began in late 2020 with an estimated completion date of December 2021.

\subsection{PC945: A Novel Inhaled Azole}

PC945 (Pulmocide, London, UK) is a novel triazole being developed for liquid nebulization for the treatment of IPA, with potential for use in ABPA. PC945 is a potent inhibitor of ergosterol synthesis, exhibiting 14-fold greater potency than voriconazole and 2.6-fold more potency than posaconazole against $A$. fumigatus [96]. A Phase 1 study in healthy volunteers and adult asthmatic patients (NCT02715570) showed that following inhalation, PC945 was slowly absorbed from the lung and led to low systemic exposure, suggesting an improved safety and DDI profile relative to oral itraconazole [97].

\section{Conclusions}

Significant advances have been made in understanding the incidence and severity of Aspergillus-related allergic diseases in patients with CF. With this understanding, more work is needed to decipher the relationship between A. fumigatus infections and different clinical outcomes. An increased appreciation of the clinical significance of ABPA has led 
to an understanding of the importance of the interactions between fungal and bacterial infections. Additional research in these areas is warranted to further characterize the complex microbial ecology of the CF lung and to help identify new treatment strategies for the management of disease. In recent years there have been several large, well-controlled clinical studies of therapies for ABPA, which have significantly improved treatments for patients and established a framework for the continued study of new therapies in development. The assessment of anti-fungal drugs with novel mechanisms of action as treatments for ABPA and other allergic fungal diseases would be a welcome step towards improving patient lives.

Author Contributions: A.K.C. and D.L.H. wrote, reviewed and edited the article. All authors have read and agreed to the published version of the manuscript.

Funding: This research received no external funding.

Institutional Review Board Statement: Not applicable.

Informed Consent Statement: Not applicable.

Conflicts of Interest: A.K.C. is an employee of Pulmatrix, a company focused on developing inhaled drugs that may be relevant to the treatment of ABPA.

\section{References}

1. Kousha, M.; Tadi, R.; Soubani, A.O. Pulmonary aspergillosis: A clinical review. Eur. Respir. Rev. 2011, 20, 156-174. [CrossRef] [PubMed]

2. Dagenais, T.R.T.; Keller, N.P. Pathogenesis of Aspergillus fumigatus in Invasive Aspergillosis. Clin. Microbiol. Rev. 2009, 22, 447-465. [CrossRef] [PubMed]

3. Yeghen, T.; Kibbler, C.C.; Prentice, H.G.; Berger, L.A.; Wallesby, R.K.; McWhinney, P.H.M.; Lampe, F.C.; Gillespie, S. Management of Invasive Pulmonary Aspergillosis in Hematology Patients: A Review of 87 Consecutive Cases at a Single Institution. Clin. Infect. Dis. 2000, 31, 859-868. [CrossRef] [PubMed]

4. Fukuda, T.; Boeckh, M.; Carter, R.A.; Sandmaier, B.M.; Maris, M.B.; Maloney, D.G.; Martin, P.J.; Storb, R.F.; Marr, K.A. Risks and outcomes of invasive fungal infections in recipients of allogeneic hematopoietic stem cell trans-plants after nonmyeloablative conditioning. Blood 2003, 102, 827-833. [CrossRef] [PubMed]

5. Denning, D.W.; Cadranel, J.; Beigelman-Aubry, C.; Ader, F.; Chakrabarti, A.; Blot, S.; Ullmann, A.J.; Dimopoulos, G.; Lange, C. Chronic pulmonary aspergillosis: Rationale and clinical guidelines for diagnosis and management. Eur. Respir. J. 2015, 47, 45-68. [CrossRef]

6. Denning, D.W.; Pashley, C.; Hartl, D.; Wardlaw, A.; Godet, C.; Del Giacco, S.; Delhaes, L.; Sergejeva, S. Fungal allergy in asthma-state of the art and research needs. Clin. Transl. Allergy 2014, 4, 14. [CrossRef] [PubMed]

7. Agarwal, R.; Sehgal, I.S.; Dhooria, S.; Muthu, V.; Prasad, K.T.; Bal, A.; Aggarwal, A.N.; Chakrabarti, A. Allergic bronchopulmonary aspergillosis. Indian J. Med. Res. 2020, 151, 529-549. [CrossRef]

8. Patel, G.; Greenberger, P.A. Allergic bronchopulmonary aspergillosis. Allergy Asthma Proc. 2019, 40, 421-424. [CrossRef] [PubMed]

9. Kuwabara, K.; Hirose, M.; Kato, K.; Yokoi, T.; Shiga, M.; Kondo, R.; Nakamura, M.; Matsunaga, K.; Horiguchi, T. Serological analysis of sensitization in allergic bronchopulmonary aspergillosis: A study on allergen components and interspecies relationships. J. Asthma 2019, 57, 610-617. [CrossRef]

10. Eickmeier, O.; Zissler, U.M.; Wittschorek, J.; Unger, F.; Schmitt-Grohé, S.; Schubert, R.; Herrmann, E.; Zielen, S. Clinical relevance of Aspergillus fumigatus sensitization in cystic fibrosis. Clin. Exp. Allergy 2019, 50, 325-333. [CrossRef] [PubMed]

11. Moss, R.B. Treatment options in severe fungal asthma and allergic bronchopulmonary aspergillosis. Eur. Respir. J. 2014, 43, 1487-1500. [CrossRef] [PubMed]

12. Patterson, K.; Strek, M.E. Allergic Bronchopulmonary Aspergillosis. Proc. Am. Thorac. Soc. 2010, 7, 237-244. [CrossRef] [PubMed]

13. Baxter, C.G.; Dunn, G.; Jones, A.M.; Webb, K.; Gore, R.; Richardson, M.D.; Denning, D.W. Novel immunologic classification of aspergillosis in adult cystic fibrosis. J. Allergy Clin. Immunol. 2013, 132, 560-566.e10. [CrossRef]

14. Denning, D.W.; Pleuvry, A.; Cole, D.C. Global burden of allergic bronchopulmonary aspergillosis with asthma and its complication chronic pulmonary aspergillosis in adults. Med. Mycol. 2013, 51, 361-370. [CrossRef]

15. Stevens, D.A.; Moss, R.B.; Kurup, V.P.; Knutsen, A.P.; Greenberger, P.; Judson, M.A.; Denning, D.W.; Crameri, R.; Brody, A.S.; Light, M.; et al. Allergic Bronchopulmonary Aspergillosis in Cystic Fibrosis-State of the Art: Cystic Fibrosis Foundation Consensus Conference. Clin. Infect. Dis. 2003, 37 (Suppl. 3), S225-S264. [CrossRef] [PubMed]

16. Maleki, M.; Mortezaee, V.; Hassanzad, M.; Mahdaviani, S.A.; Poorabdollah, M.; Mehrian, P.; Behnampour, N.; Mirenayat, M.S.; Abastabar, M.; Tavakoli, M.; et al. Prevalence of allergic bronchopulmonary aspergillosis in cystic fibrosis patients using two different diagnos-tic criteria. Eur. Ann. Allergy Clin. Immunol. 2020, 52, 104-111. [CrossRef] [PubMed] 
17. Amin, R.; Dupuis, A.; Aaron, S.D.; Ratjen, F. The Effect of Chronic Infection with Aspergillus fumigatus on Lung Function and Hospitalization in Patients with Cystic Fibrosis. Chest 2010, 137, 171-176. [CrossRef] [PubMed]

18. De Vrankrijker, A.M.M.; van der Ent, C.K.; van Berkhout, F.T.; Stellato, R.K.; Willems, R.J.L.; Bonten, M.J.M.; Wolfs, T.F.W. Aspergillus fumigatus colonization in cystic fibrosis: Implications for lung function? Clin. Microbiol. Infect. 2011, 17, 1381-1386. [CrossRef] [PubMed]

19. Pihet, M.; Carrere, J.; Cimon, B.; Chabasse, D.; Delhaes, L.; Symoens, F.; Bouchara, J.-P. Occurrence and relevance of filamentous fungi in respiratory secretions of patients with cystic fibrosis-A review. Med Mycol. 2009, 47, 387-397. [CrossRef] [PubMed]

20. Sabino, R.; Ferreira, J.A.; Moss, R.B.; Valente, J.; Veríssimo, C.; Carolino, E.; Clemons, K.V.; Everson, C.; Banaei, N.; Penner, J.; et al. Molecular epidemiology of Aspergillus collected from cystic fibrosis patients. J. Cyst. Fibros. 2015, 14, 474-481. [CrossRef]

21. Lipuma, J.J. The Changing Microbial Epidemiology in Cystic Fibrosis. Clin. Microbiol. Rev. 2010, 23, 299-323. [CrossRef] [PubMed]

22. Bargon, J.; Dauletbaev, N.; Köhler, B.; Wolf, M.; Posselt, H.-G.; Wagner, T. Prophylactic antibiotic therapy is associated with an increased prevalence of Aspergillus colonization in adult cystic fibrosis patients. Respir. Med. 1999, 93, 835-838. [CrossRef]

23. Breuer, O.; Schultz, A.; Turkovic, L.; De Klerk, N.; Keil, A.D.; Brennan, S.; Harrison, J.; Robertson, C.; Robinson, P.J.; Sly, P.D.; et al. Changing Prevalence of Lower Airway Infections in Young Children with Cystic Fibrosis. Am. J. Respir. Crit. Care Med. 2019, 200, 590-599. [CrossRef]

24. Saunders, R.V.; Modha, D.E.; Claydon, A.; Gaillard, E.A. Chronic Aspergillus fumigatus colonization of the pediatric cystic fibrosis airway is common and may be associated with a more rapid decline in lung function. Med. Mycol. 2016, 54, 537-543. [CrossRef] [PubMed]

25. Ramsey, K.A.; Hart, E.; Turkovic, L.; Padros-Goossens, M.; Stick, S.M.; Ranganathan, S.C. Respiratory infection rates differ between geographically distant paediatric cystic fibrosis cohorts. ERJ Open Res. 2016, 2, 00014-02016. [CrossRef] [PubMed]

26. Fillaux, J.; Brémont, F.; Murris, M.; Cassaing, S.; Rittié, J.-L.; Tétu, L.; Segonds, C.; Abbal, M.; Bieth, E.; Berry, A.; et al. Assessment of Aspergillus sensitization or persistent carriage as a factor in lung function impairment in cystic fibrosis patients. Scand. J. Infect. Dis. 2012, 44, 842-847. [CrossRef] [PubMed]

27. Noni, M.; Katelari, A.; Dimopoulos, G.; Doudounakis, S.-E.; Tzoumaka-Bakoula, C.; Spoulou, V. Aspergillus fumigatus chronic colonization and lung function decline in cystic fibrosis may have a two-way relationship. Eur. J. Clin. Microbiol. Infect. Dis. 2015, 34, 2235-2241. [CrossRef] [PubMed]

28. Hong, G.; Alby, K.; Ng, S.C.; Fleck, V.; Kubrak, C.; Rubenstein, R.C.; Dorgan, D.J.; Kawut, S.M.; Hadjiliadis, D. The presence of Aspergillus fumigatus is associated with worse respiratory quality of life in cystic fibrosis. J. Cyst. Fibros. 2020, 19, 125-130. [CrossRef]

29. Gangell, C.; Gard, S.; Douglas, T.; Park, J.; De Klerk, N.; Keil, T.; Brennan, S.; Ranganathan, S.; Robins-Browne, R.; Sly, P.D.; et al. Inflammatory Responses to Individual Microorganisms in the Lungs of Children With Cystic Fibrosis. Clin. Infect. Dis. 2011, 53, 425-432. [CrossRef] [PubMed]

30. Breuer, O.; Schultz, A.; Garratt, L.W.; Turkovic, L.; Rosenow, T.; Murray, C.P.; Karpievitch, Y.V.; Akesson, L.; Dalton, S.; Sly, P.D.; et al. Aspergillus Infections and Progression of Structural Lung Disease in Children with Cystic Fibrosis. Am. J. Respir. Crit. Care Med. 2020, 201, 688-696. [CrossRef] [PubMed]

31. Harun, S.N.; Wainwright, C.E.; Grimwood, K.; Hennig, S. Aspergillus and progression of lung disease in children with cystic fibrosis. Thorax 2019, 74, 125-131. [CrossRef] [PubMed]

32. Agarwal, R.; Chakrabarti, A.; Shah, A.; Gupta, D.; Meis, J.F.; Guleria, R.; Moss, R.; Denning, D.W.; ABPA Complicating Asthma ISHAM Working Group. Allergic bronchopulmonary aspergillosis: Review of literature and proposal of new diagnostic and classifica-tion criteria. Clin. Exp. Allergy 2013, 43, 850-873. [CrossRef] [PubMed]

33. Reece, E.; McClean, S.; Greally, P.; Renwick, J. The prevalence of Aspergillus fumigatus in early cystic fibrosis disease is underestimated by culture-based diagnostic methods. J. Microbiol. Methods 2019, 164, 105683. [CrossRef] [PubMed]

34. Fraczek, M.G.; Kirwan, M.B.; Moore, C.B.; Morris, J.; Denning, D.W.; Richardson, M.D. Volume dependency for culture of fungi from respiratory secretions and increased sensitivity of Asper-gillus quantitative PCR. Mycoses 2014, 57, 69-78. [CrossRef]

35. Armstead, J.; Morris, J.; Denning, D.W. Multi-Country Estimate of Different Manifestations of Aspergillosis in Cystic Fibrosis PLoS ONE 2014, 9, e98502. [CrossRef] [PubMed]

36. Briard, B.; Mislin, G.L.A.; Latgé, J.-P.; Beauvais, A. Interactions between Aspergillus fumigatus and Pulmonary Bacteria: Current State of the Field, New Data, and Future Perspective. J. Fungi 2019, 5, 48. [CrossRef] [PubMed]

37. Granchelli, A.M.; Adler, F.R.; Keogh, R.H.; Kartsonaki, C.; Cox, D.R.; Liou, T.G. Microbial Interactions in the Cystic Fibrosis Airway. J. Clin. Microbiol. 2018, 56. [CrossRef]

38. Esther, C.R., Jr.; Esserman, D.A.; Gilligan, P.; Kerr, A.; Noone, P.G. Chronic Mycobacterium abscessus infection and lung function decline in cystic fibrosis. J. Cyst. Fibros. 2010, 9, 117-123. [CrossRef]

39. Monin, L.; Mehta, S.; Elsegeiny, W.; Gopal, R.; McAleer, J.P.; Oury, T.D.; Kolls, J.; Khader, S.A. Aspergillus fumigatus Preexposure Worsens Pathology and Improves Control of Mycobacterium abscessus Pulmonary Infection in Mice. Infect. Immun. 2017, 86, e00859-17. [CrossRef] [PubMed]

40. Sass, G.; Nazik, H.; Penner, J.; Shah, H.; Ansari, S.R.; Clemons, K.V.; Groleau, M.-C.; Dietl, A.-M.; Visca, P.; Haas, H.; et al. Aspergillus-Pseudomonas interaction, relevant to competition in airways. Med Mycol. 2019, 57 (Suppl. 2), S228-S232. [CrossRef] 
41. Mowat, E.; Rajendran, R.; Williams, C.; McCulloch, E.; Jones, B.; Lang, S.; Ramage, G. Pseudomonas aeruginosa and their small diffusible extracellular molecules inhibit Aspergillus fumigatus biofilm formation. FEMS Microbiol. Lett. 2010, 313, 96-102. [CrossRef] [PubMed]

42. Seidler, M.J.; Salvenmoser, S.; Muller, F.M. Aspergillus fumigatus forms biofilms with reduced antifungal drug susceptibil-ity on bronchial epithelial cells. Antimicrob. Agents Chemother. 2008, 52, 4130-4136. [CrossRef] [PubMed]

43. Davies, J.C.; Bilton, D. Bugs, biofilms, and resistance in cystic fibrosis. Respir. Care 2009, 54, 628-640. [CrossRef] [PubMed]

44. Shirazi, F.; Ferreira, J.A.G.; Stevens, D.A.; Clemons, K.V.; Kontoyiannis, D.P. Biofilm Filtrates of Pseudomonas aeruginosa Strains Isolated from Cystic Fibrosis Patients Inhibit Preformed Aspergillus fumigatus Biofilms via Apoptosis. PLoS ONE 2016, 11, e0150155. [CrossRef]

45. Sass, G.; Nazik, H.; Penner, J.; Shah, H.; Ansari, S.R.; Clemons, K.V.; Groleau, M.C.; Dietl, A.M.; Visca, P.; Haas, H.; et al. Studies of Pseudomonas aeruginosa Mutants Indicate Pyoverdine as the Central Factor in Inhibition of As-pergillus fumigatus Biofilm. J. Bacteriol. 2017, 200, e00345-17. [CrossRef] [PubMed]

46. Melloul, E.; Luiggi, S.; Anaïs, L.; Arné, P.; Costa, J.-M.; Fihman, V.; Briard, B.; Dannaoui, E.; Guillot, J.; Decousser, J.-W.; et al. Characteristics of Aspergillus fumigatus in Association with Stenotrophomonas maltophilia in an In Vitro Model of Mixed Biofilm. PLoS ONE 2016, 11, e0166325. [CrossRef] [PubMed]

47. Roisin, L.; Melloul, E.; Woerther, P.-L.; Royer, G.; Decousser, J.-W.; Guillot, J.; Dannaoui, E.; Botterel, F. Modulated Response of Aspergillus fumigatus and Stenotrophomonas maltophilia to Antimicrobial Agents in Polymicrobial Biofilm. Front. Cell. Infect. Microbiol. 2020, 10, 574028. [CrossRef] [PubMed]

48. Greenberger, P.A.; Bush, R.K.; Demain, J.G.; Luong, A.; Slavin, R.G.; Knutsen, A.P. Allergic bronchopulmonary aspergillosis. J. Allergy Clin. Immunol. Pract. 2014, 2, 703-708. [CrossRef] [PubMed]

49. Agarwal, R.; Aggarwal, A.N.; Dhooria, S.; Sehgal, I.S.; Garg, M.; Saikia, B.; Behera, D.; Chakrabarti, A. A randomised trial of glucocorticoids in acute-stage allergic bronchopulmonary aspergillosis complicating asthma. Eur. Respir. J. 2015, 47, 490-498. [CrossRef] [PubMed]

50. Tracy, M.C.; Okorie, C.U.A.; Foley, E.A.; Moss, R.B. Allergic Bronchopulmonary Aspergillosis. J. Fungi 2016, 2, 17. [CrossRef] [PubMed]

51. Gupta, R.K.; Chandr, A.; Gautam, P.B. Allergic bronchopulmonary aspergillosis-A clinical review. J. Assoc. Physicians India 2012, $60,46-51$.

52. Agarwal, R.; Dhooria, S.; Sehgal, I.S.; Aggarwal, A.N.; Garg, M.; Saikia, B.; Behera, D.; Chakrabarti, A. A Randomized Trial of Itraconazole vs Prednisolone in Acute-Stage Allergic Bronchopulmonary Aspergil-losis Complicating Asthma. Chest 2018, 153, 656-664. [CrossRef] [PubMed]

53. Wark, P.A.B.; Hensley, M.J.; Saltos, N.; Boyle, M.J.; Toneguzzi, R.C.; Epid, G.D.C.; Simpson, J.L.; McElduff, P.; Gibson, P.G. Anti-inflammatory effect of itraconazole in stable allergic bronchopulmonary aspergillosis: A randomized controlled trial. J. Allergy Clin. Immunol. 2003, 111, 952-957. [CrossRef] [PubMed]

54. Stevens, D.A.; Schwartz, H.J.; Lee, J.Y.; Moskovitz, B.L.; Jerome, D.C.; Catanzaro, A.; Bamberger, D.M.; Weinmann, A.J.; Tuazon, C.U.; Judson, M.A.; et al. A Randomized Trial of Itraconazole in Allergic Bronchopulmonary Aspergillosis. N. Engl. J. Med. 2000, 342, 756-762. [CrossRef] [PubMed]

55. Agarwal, R.; Dhooria, S.; Sehgal, I.S.; Aggarwal, A.N.; Garg, M.; Saikia, B.; Chakrabarti, A. A randomised trial of voriconazole and prednisolone monotherapy in acute-stage allergic bronchopulmo-nary aspergillosis complicating asthma. Eur. Respir. J. 2018, 52, 1801159. [CrossRef] [PubMed]

56. Chishimba, L.; Langridge, P.; Powell, G.; Niven, R.M.; Denning, D.W. Efficacy and safety of nebulised amphotericin B (NAB) in severe asthma with fungal sensitisation (SAFS) and allergic bronchopulmonary aspergillosis (ABPA). J. Asthma 2014, 52, 289-295. [CrossRef] [PubMed]

57. Chmiel, J.F.; Konstan, M.W. Anti-inflammatory medications for cystic fibrosis lung disease: Selecting the most appropriate agent. Treat. Respir. Med. 2005, 4, 255-273. [CrossRef] [PubMed]

58. Liu, D.; Ahmet, A.; Ward, L.; Krishnamoorthy, P.; Mandelcorn, E.D.; Leigh, R.; Brown, J.P.; Cohen, A.; Kim, H. A practical guide to the monitoring and management of the complications of systemic corticosteroid therapy. Allergy Asthma Clin. Immunol. 2013, 9, 30. [CrossRef]

59. Moss, R.B. Treating allergic bronchopulmonary aspergillosis: The way forward. Eur. Respir. J. 2016, 47, 385-387. [CrossRef]

60. Fairs, A.; Agbetile, J.; Hargadon, B.; Bourne, M.; Monteiro, W.R.; Brightling, C.E.; Bradding, P.; Green, R.H.; Mutalithas, K.; Desai, D.; et al. IgE Sensitization toAspergillus fumigatusIs Associated with Reduced Lung Function in Asthma. Am. J. Respir. Crit. Care Med. 2010, 182, 1362-1368. [CrossRef]

61. Aimanianda, V.; Bayry, J.; Bozza, S.; Kniemeyer, O.; Perruccio, K.; Elluru, S.R.; Clavaud, C.; Paris, S.; Brakhage, A.A.; Kaveri, S.V.; et al. Surface hydrophobin prevents immune recognition of airborne fungal spores. Nat. Cell Biol. 2009, 460, 1117-1121. [CrossRef]

62. Green, B.J.; Mitakakis, T.Z.; Tovey, E.R. Allergen detection from 11 fungal species before and after germination. J. Allergy Clin. Immunol. 2003, 111, 285-289. [CrossRef] [PubMed]

63. Kurup, V.P.; Knutsen, A.P.; Moss, R.B.; Bansal, N.K. Specific antibodies to recombinant allergens of Aspergillus fumigatus in cystic fibrosis patients with ABPA. Clin. Mol. Allergy 2006, 4, 11. [CrossRef] [PubMed] 
64. Moreira, A.S.; Silva, D.; Ferreira, A.R.; Delgado, L. Antifungal treatment in allergic bronchopulmonary aspergillosis with and without cystic fibrosis: A sys-tematic review. Clin. Exp. Allergy 2014, 44, 1210-1227. [CrossRef] [PubMed]

65. Farrant, J.; Brice, H.; Fowler, S.; Niven, R. Fungal sensitisation in severe asthma is associated with the identification of Aspergillus fumigatus in spu-tum. J. Asthma 2016, 53, 732-735. [CrossRef] [PubMed]

66. Cowen, L.E.; Steinbach, W.J. Stress, Drugs, and Evolution: The Role of Cellular Signaling in Fungal Drug Resistance. Eukaryot. Cell 2008, 7, 747-764. [CrossRef] [PubMed]

67. Chrdle, A.; Mustakim, S.; Bright-Thomas, R.J.; Baxter, C.G.; Felton, T.; Denning, D.W. Aspergillus bronchitis without significant immunocompromise. Ann. N. Y. Acad. Sci. 2012, 1272, 73-85. [CrossRef] [PubMed]

68. Denning, D.W.; Van Wye, J.E.; Lewiston, N.J.; Stevens, D.A. Adjunctive Therapy of Allergic Bronchopulmonary Aspergillosis with Itraconazole. Chest 1991, 100, 813-819. [CrossRef]

69. Denning, D.W.; Park, S.; Lass-Florl, C.; Fraczek, M.G.; Kirwan, M.; Gore, R.; Smith, J.; Bueid, A.; Moore, C.B.; Bowyer, P.; et al. High-frequency Triazole Resistance Found in Nonculturable Aspergillus fumigatus from Lungs of Patients with Chronic Fungal Disease. Clin. Infect. Dis. 2011, 52, 1123-1129. [CrossRef]

70. Jørgensen, K.M.; Guinea, J.; Meletiadis, J.; Hare, R.K.; Arendrup, M.C. Revision of EUCAST breakpoints: Consequences for susceptibility of contemporary Danish mould isolates to isavuconazole and comparators. J. Antimicrob. Chemother. 2020, 75, 2573-2581. [CrossRef]

71. Gonzalez-Jimenez, I.; Lucio, J.; Amich, J.; Cuesta, I.; Arroyo, R.S.; Alcazar-Fuoli, L.; Mellado, E. A Cyp51B Mutation Contributes to Azole Resistance in Aspergillus fumigatus. J. Fungi 2020, 6, 315. [CrossRef]

72. Nepomuceno, I.B.; Esrig, S.; Moss, R.B. Allergic bronchopulmonary aspergillosis in cystic fibrosis: Role of atopy and re-sponse to itraconazole. Chest 1999, 115, 364-370. [CrossRef] [PubMed]

73. Chishimba, L.; Niven, R.M.; Cooley, J.; Denning, D.W. Voriconazole and Posaconazole Improve Asthma Severity in Allergic Bronchopulmonary Aspergillosis and Severe Asthma with Fungal Sensitization. J. Asthma 2012, 49, 423-433. [CrossRef] [PubMed]

74. Patel, D.; Popple, S.; Claydon, A.; Modha, D.E.; Gaillard, E.A. Posaconazole therapy in children with cystic fibrosis and Aspergillus-related lung disease. Med. Mycol. 2019, 58, 11-21. [CrossRef] [PubMed]

75. Hilliard, T.; Edwards, S.; Buchdahl, R.; Francis, J.; Rosenthal, M.; Balfour-Lynn, I.; Bush, A.; Davies, J. Voriconazole therapy in children with cystic fibrosis. J. Cyst. Fibros. 2005, 4, 215-220. [CrossRef] [PubMed]

76. Periselneris, J.; Nwankwo, L.; Schelenz, S.; Shah, A.; Armstrong-James, D. Posaconazole for the treatment of allergic bronchopulmonary aspergillosis in patients with cystic fibro-sis. J. Antimicrob. Chemother. 2019, 74, 1701-1703. [CrossRef] [PubMed]

77. Eigen, H.; Rosenstein, B.J.; FitzSimmons, S.; Schidlow, D.V. A multicenter study of alternate-day prednisone therapy in patients with cystic fibrosis. Cystic Fibrosis Foundation Prednisone Trial Group. J. Pediatr. 1995, 126, 515-523. [CrossRef]

78. Bhudhikanok, G.S.; Lim, J.; Marcus, R.; Harkins, A.; Moss, R.B.; Bachrach, L.K. Correlates of osteopenia in patients with cystic fibrosis. Pediatrics 1996, 97, 103-111. [PubMed]

79. Batista, M.; Costa, S.; Shikanai-Yasuda, M.; Moss, R. Current treatment options for invasive aspergillosis. Drugs Today 2013, 49, 213. [CrossRef] [PubMed]

80. Ram, B.; Aggarwal, A.N.; Dhooria, S.; Sehgal, I.S.; Garg, M.; Behera, D.; Chakrabarti, A.; Agarwal, R. A pilot randomized trial of nebulized amphotericin in patients with allergic bronchopulmonary aspergillosis. J. Asthma 2016, 53, 517-524. [CrossRef] [PubMed]

81. Otu, A.A.; Langridge, P.; Denning, D.W. An evaluation of nebulised amphotericin B deoxycholate (Fungizone ${ }^{\odot}$ ) for treatment of pulmonary aspergillosis in the UK National Aspergillosis Centre. Mycoses 2019, 62, 1049-1055. [CrossRef] [PubMed]

82. Galli, S.J.; Tsai, M. IgE and mast cells in allergic disease. Nat. Med. 2012, 18, 693-704. [CrossRef] [PubMed]

83. Koutsokera, A.; Corriveau, S.; Sykes, J.; Coriati, A.; Cortes, D.; Vadas, P.; Chaparro, C.; McIntyre, K.; Tullis, E.; Stephenson, A.L. Omalizumab for asthma and allergic bronchopulmonary aspergillosis in adults with cystic fibrosis. J. Cyst. Fibros. 2020, 19, 119-124. [CrossRef] [PubMed]

84. Parisi, G.F.; Portale, A.; Papale, M.; Tardino, L.; Rotolo, N.; Licari, A.; Leonardi, S. Successful treatment with omalizumab of allergic bronchopulmonary aspergillosis in patients with cystic fibrosis: Case reports and literature review. J. Allergy Clin. Immunol. Pract. 2019, 7, 1636-1638. [CrossRef] [PubMed]

85. Perisson, C.; Destruys, L.; Grenet, D.; Bassinet, L.; Derelle, J.; Sermet-Gaudelus, I.; Thumerelle, C.; Prevotat, A.; Rosner, V.; Clement, A.; et al. Omalizumab treatment for allergic bronchopulmonary aspergillosis in young patients with cystic fibrosis. Respir. Med. 2017, 133, 12-15. [CrossRef] [PubMed]

86. Ashkenazi, M.; Sity, S.; Sarouk, I.; Aluma, B.e.; Dagan, A.; Bezalel, Y.; Bentur, L.; de Boeck, K.; Efrati, O. Omalizumab in allergic bronchopulmonary aspergillosis in patients with cystic fibrosis. J. Asthma Allergy 2018, 11, 101-107. [CrossRef]

87. Prentice, A.G.; Glasmacher, A. Making sense of itraconazole pharmacokinetics. J. Antimicrob. Chemother. 2005, 56 (Suppl. 1), i17-i22. [CrossRef]

88. Sermet-Gaudelus, I.; Lesne-Hulin, A.; Lenoir, G.; Singlas, E.; Berche, P.; Hennequin, C. Sputum Itraconazole Concentrations in Cystic Fibrosis Patients. Antimicrob. Agents Chemother. 2001, 45, 1937-1938. [CrossRef]

89. Aaron, S.D.; Vandemheen, K.L.; Freitag, A.; Pedder, L.; Cameron, W.; Lavoie, A.; Paterson, N.; Wilcox, P.; Rabin, H.; Tullis, E.; et al. Treatment of Aspergillus fumigatus in Patients with Cystic Fibrosis: A Randomized, Placebo-Controlled Pilot Study. PLoS ONE 2012, 7, e36077. [CrossRef] 
90. Abbotsford, J.; Foley, D.A.; Goff, Z.; Bowen, A.C.; Blyth, C.C.; Yeoh, D.K. Clinical experience with SUBA-itraconazole at a tertiary paediatric hospital. J. Antimicrob. Chemother. 2021, 76, 249-252. [CrossRef]

91. Singh, D.; Ravi, A.; Kane, K.; Schmalbach, T.; Hava, D.L. The pharmacokinetics, pharmacodynamics and tolerability of PUR0200, a novel tiotropium formulation, in chronic obstructive pulmonary disease. Br. J. Clin. Pharmacol. 2018, 84, 2097-2105. [CrossRef] [PubMed]

92. Hava, D.L.; Tan, L.; Johnson, P.; Curran, A.K.; Perry, J.; Kramer, S.; Kane, K.; Bedwell, P.; Layton, G.; Swann, C.; et al. A phase 1/1b study of PUR1900, an inhaled formulation of itraconazole, in healthy volunteers and asthmat-ics to study safety, tolerability and pharmacokinetics. Br. J. Clin. Pharmacol. 2020, 86, 723-733. [CrossRef] [PubMed]

93. Caponetti, G.; Maggi, L.; Sardina, M.; Castegini, F.; Raiteri, L.; Salerio, I.; Kottakis, I.; van Holsbeke, C.; De Backer, J.; Vos, W. EDRY®an Innovative Dry Powder Technology Evaluated via Functional Respiratory Imaging. Eur. Respir. J. 2016, 48, PA958.

94. Beinborn, N.A.; Du, J.; Wiederhold, N.P.; Smyth, H.D.; Williams, R.O. Dry powder insufflation of crystalline and amorphous voriconazole formulations produced by thin film freezing to mice. Eur. J. Pharm. Biopharm. 2012, 81, 600-608. [CrossRef] [PubMed]

95. Beinborn, N.A.; Lirola, H.L.; Williams, R.O. Effect of process variables on morphology and aerodynamic properties of voriconazole formulations produced by thin film freezing. Int. J. Pharm. 2012, 429, 46-57. [CrossRef] [PubMed]

96. Colley, T.; Alanio, A.; Kelly, S.L.; Sehra, G.; Kizawa, Y.; Warrilow, A.G.S.; Parker, J.E.; Kelly, D.E.; Kimura, G.; Anderson-Dring, L.; et al. In Vitro and In Vivo Antifungal Profile of a Novel and Long-Acting Inhaled Azole, PC945, on Aspergillus fumigatus Infection. Antimicrob. Agents Chemother. 2017, 61, e02280-16. [CrossRef] [PubMed]

97. Cass, L.; Murray, A.; Davis, A.; Woodward, K.; Albayaty, M.; Ito, K.; Strong, P.; Ayrton, J.; Brindley, C.; Prosser, J.; et al. Safety and nonclinical and clinical pharmacokinetics of PC945, a novel inhaled triazole antifungal agent. Pharmacol. Res. Perspect. 2021, 9, e00690. [CrossRef] 